\title{
Role of the Delorme Procedure for Rectal Prolapse in Young Patients
}

\author{
Yong Hee Hwang \\ Department of Surgery, Sahmyook Medical Center, Seoul, Korea
}

\section{See Article on Page 60-65}

It is known that patients with a short, full-thickness rectal prolapse can be treated with a mucosal sleeve resection; however, for a longer prolapse, a mucosal sleeve resection is associated with a higher recurrence rate compared with abdominal approaches. Thus, the Delorme procedure has been advocated for those who are considered "high risk" for an abdominal procedure because of comorbidities or to avoid the risk of nerve damage [1]. However, the recurrence rates are significantly different between younger patients with good pelvic floor musculature and elderly patients with a weak pelvic floor, a gaping anus, and a sliding hernia of the cul-de-sac $[2,3]$. Constipation and fecal Incontinence improve following a Delorme operation, but urgency and tenesmus do occur. Improved anal sphincter and rectal sensation is associated with a reduced incidence of defecatory problems after a Delorme's procedure [4]. The Delorme procedure has a role in the treatment of rectal prolapse in young patients.

\section{REFERENCES}

1. Varma M, Rafferty J, Buie WD; Standards Practice Task Force of American Society of Colon and Rectal Surgeons. Practice parameters for the management of rectal prolapse. Dis Colon Rectum 2011;54:1339-46.

2. Lieberth M, Kondylis LA, Reilly JC, Kondylis PD. The Delorme repair for full-thickness rectal prolapse: a retrospective review. Am J Surg 2009;197:418-23.

3. Lechaux JP, Lechaux D, Perez M. Results of Delorme's procedure for rectal prolapsed: advantages of a modified technique. Dis Colon Rectum 1995;38:301-7.

4. Tsunoda A, Yasuda N, Yokoyama N, Kamiyama G, Kusano M. Delorme's procedure for rectal prolapse: clinical and physiological analysis. Dis Colon Rectum 2003;46:1260-5.

Correspondence to: Yong Hee Hwang, M.D.

Department of Sugery, Sahmyook Medical Center, 82 Mangu-ro,

Dongdaemun-gu, Seoul 130-711, Korea

Tel: +82-2-2210-3563, Fax: +82-2-2212-2673

E-mail: hwangyon@hotmail.com

(C) 2013 The Korean Society of Coloproctology

This is an open-access article distributed under the terms of the Creative Commons Attribution Non-

Commercial License (http://creativecommons.org/licenses/by-nc/3.0) which permits unrestricted non-

commercial use, distribution, and reproduction in any medium, provided the original work is properly cited. 